\title{
Economic Impacts of Tourism Industry
}

\author{
Fateme Tohidy Ardahaey (PhD) \\ Faculty of Management and Economics \\ Science and Research Branch, Islamic Azad University, Tehran, Iran \\ E-mail: ftohidy.ardahaey@gmail.com
}

Received: November 1, $2010 \quad$ Accepted: March 9, 2011 doi:10.5539/ijbm.v6n8p206

\begin{abstract}
This article is concerned with the economic impacts of tourism industry, especially in developing countries. It initially reviews the concept and using a model, it deals with the factors affecting the economic impacts associated with tourism. The research findings indicated that with short-term and long-term strategic planning and using the specific abilities and tourism products of developing countries, which suffer from some indices as unemployment, limits in earning and currency flows, inflation and other problems, most of their economic problems can be solved.
\end{abstract}

Keywords: Tourism, Economic impacts, Economic development, Developing countries

\section{Introduction}

Typically, tourism can be thought of as a bundle of goods and services combined together with a fixed proportion. This is because tourists, for instance, cannot substitute transportation for food, hotels or other services. This is the same assumption used by Blake and Gillham (2001). Outbound tourism demanded by households is a function of disposable incomes. Inbound tourism demanded by foreigners is a function of tourism prices and exchange rates (Wattanakuljarus, 2006).

Tourism is not an industry per se but a collection of interrelated industries, which sell products to tourists as well as to a range of other customers: hotels, tour operators and travel agents, airlines, etc.

Tourism consumption usually leads to increased output, prices and wages in the industries that sell products directly to tourists. Therefore, poor households are likely to be negatively affected via the price channel; rising price will reduce the real income effect. The largest increases in prices that result are, in general, for the types of goods and services that tourists consume. These are products that domestic residents only usually consume if they take a trip (accommodation, passenger transport, tour agency and operation services, recreational services, and souvenir goods), if they go to restaurants or if they buy food products. Most products are those purchased more by higher income households; the direct effect of the channel will lead to small increases in prices paid by poor households, through food products. Even in this case, tourists tend to buy a different set of food from those consumed by poor Households (Laffargue, 2009).

Poor households can benefit from the higher wages and increases in production in tourism related industries. This effect might be moderate, however, if the poor households lack the skill required for employment in these businesses. An offsetting earnings effect comes from the fall in production and wages in traditional export sectors. An adverse aspect of tourism expansion is that if the poor rely heavily on earnings from commodity export sectors, an increase in tourism demand may lead to an increase in poverty.

Tourism consumption (for example domestic tourism) is mainly concentrated upon the wealthiest sections of society. On the other hand, the remuneration of households through the industry is increasingly concentrated, in relative terms, towards the lowest- and low- income households. These data suggest a distribution of income from the richest, through consumption, to the poorest, through remuneration. It is notable that the largest inter-household flows are from high-to low-income households, but not to the lowest income ones.

Finally, in Brazil while the poor do not benefit greatly from tourism, they are not heavily involved in other exporting sectors, so do not lose out. In Kenya, Tanzania and Uganda, they receive more income from non-service exports (such as coffee and tea) than they do from tourism (or, the hotel and restaurant sector, Blake, 2008a). The conclusion has to be that tourism can make the poor worse off, which is a result that Wattanakuljarus and Cixhead (2008) obtain for Thailand.

With stimulation of international tourism, there is a strengthening of the exchange rate. This movement leads to import substitution and the contraction of traditional export sectors of mining and agriculture which, with the high import content of the tourism sector, causes the balance of trade to worsen. Some sectors experience direct stimulation (air transport, restaurants and hotels), others experience indirect stimulation due to the rising prices of intermediary inputs supplied to the tourism sector (food, clothing) and other contract as the result of adverse 
exchange rate effects (Laffargue, 2009).

Tourism is now, more than ever, recognized as a major economic contributor in many destinations worldwide, adding value for foreign exchange but also support for export industries and environmental, social, cultural, and historic resources support and protection (Antigua and Barbuda Tourism Development Programme, 2003).

Businesses and public organizations are increasingly interested in the economic impacts of tourism at national, state, and local levels. Tourism's economic benefits are touted by the industry for a variety of reasons. Claims of tourism's economic significance give the industry greater respect among the business community, public officials, and the public in general. This often translates into decisions or public policies that are favorable to tourism. Community support is important for tourism, as it is an activity that affects the entire community. Tourism businesses depend extensively on each other as well as on other businesses, government and residents of the local community.

Economic benefits and costs of tourism reach virtually everyone in the region in one way or another. Economic impact analyses provide tangible estimates of these economic interdependencies and a better understanding of the role and importance of tourism in a region's economy.

Tourism activity also involves economic costs, including the direct costs incurred by tourism businesses, government costs for infrastructure to better serve tourists, as well as congestion and related costs borne by individuals in the community. Community decisions over tourism often involve debates between industry proponents touting tourism's economic impacts (benefits) and detractors emphasizing tourism's costs. Sound decisions rest on a balanced and objective assessment of both benefits and costs and an understanding of who benefits from tourism and who pays for it.

One positive aspect of tourism is its ability to bring new money into the community. Multipliers in industries that serve tourists are relatively high because wages and salaries are such a large part of the industries' total expenses. The impacts of tourism can be increased by selling local products and by helping local people retain ownership of businesses that serve tourists. Agricultural tourism is particularly high in impacts because the labor used, business ownership and the products sold are usually local (Stynes, 1997).

There are two basic ways for a community or a business to increase revenues from tourism. Either increase the number of visitors or increase the amount that each visitor spends. This is why local chambers of commerce have devoted so much of their resources to attracting more visitors to the area. In an area that may have limited visitor accommodations, attracting day visitors may be the most effective strategy to pursue. However, in communities that do have hotels and other lodging, convincing visitors to stay overnight is the most effective way to increase visitor expenditures. Not only do such visitors spend additional money on lodging, they eat more meals in the community and have more time to shop in local stores. In most surveys of visitors, shopping is one of the most popular vacation activities.

An effective way for individual businesses to increase their sales to visitors is to offer a range of products and services that will keep the visitor at their outlets longer. Many grocery stores are arranged to slow shoppers down because typically the longer a person is in a store, the more they are likely to spend (Leones, 1995).

Tourism's economic impacts are therefore an important consideration in state, regional and community planning and economic development. Economic impacts are also important factors in marketing and management decisions. Communities therefore need to understand the relative importance of tourism to their region, including tourism's contribution to economic activity in the area (Stynes, 1997).

\section{Tourism and its Economic Impacts}

\subsection{Concepts and Definitions}

Economic impacts associated with tourism arise as a result of the demand and supply relationships in the industry, the associated visitor and investment expenditure patterns that they stimulate, and the structure of the economy. The demand/supply factors influence the number of visitors, their length of stay, and their expenditure patterns while the economy's structural characteristics determine its propensity to re-circulate those expenditures internally. The more rounds of circulation generated within the economy, the greater the multiplier effect of the initial stimulus (Antigua and Barbuda Tourism Development Programme, 2003).

\subsection{Background Factors}

The tourism industry is dominated by a few powerful corporations, most of which are based in the West (Mann, 2000), thus it caters for a market of Western tourists. The consequences are that the wishes and needs of the receiving countries are mostly neglected. Tourism could be the source of greater economic benefits for the less developed countries in the world. However, at the moment there is a considerable amount of leakage, as the greatest part of the benefits generated from tourism rest within the sending countries of the West. Currently there are large operators monopolizing the market as they cover a number of the sectors, such as accommodation and transport.

Thus the production, the delivery and the marketing of a product might be operated by one company in terms of vertical integration (Kalisch 1996). This phenomenon makes it very difficult for the local entrepreneurs to 
compete and as they need the tour operators and the airlines to supply the customers, the transnational corporations are let to rule. Furthermore, as local populations rarely are involved in tourism planning or implementation of tourism projects, the industry has contributed to the marginalization of many people and expanding the unequal gap between the rich and the poor. The power lies in the hands of the multinational corporations and in many instances tourism can be referred to as neocolonialism, perpetuating dependency. According to Mann (2000), the World Bank estimates that 55 pence out of every $£ 1$ spent on holidays in less developed countries, returns to the West and much of the rest goes to the business-elite in the capitals of the less developed countries. As tourism keeps on spreading, it needs new destinations, which has lead to the fact that tourism in less developed countries is growing (Tourism Concern, 1999).

This is partly due to the fact that the image of the less developed countries has changed in the eyes of the advanced world (Mowforth and Munt 1998, 1-2). The basic package tour destinations such as Greece and Spain are now challenged by long-haul package holidays to Africa, Asia and Latin America. The emphasis is on all-inclusive holidays, operated by transnational tourism corporations. This re-enforces the danger of returning to a kind of new colonialism and unfair trading conditions, as most of the destinations in question are poor and lack the infrastructure and tourism expertise that would be needed in order to cope. As a result of this, most of the profits of tourism risk flowing back to the industrialized nations and the host destination remains poor, receiving either an unfair and low return or suffering from deterioration of their living caused by negative effects of the tourism activity (Tourism Concern, 1999).

Many less developed countries have seen tourism as a quick chance of gaining economic profit and tourism has thus become a rival to, for example, agriculture, and in many cases thereby a mono-crop. As these countries are generally poor and largely in debt and without previous experience of the tourism industry, tourism infrastructure developments rely heavily on foreign investments. These investments tend to exhaust the national economy as well as the local communities' resources such as water and electricity.

Imports are usually increased because of the taste of the tourists, and usually these imports tend to get more expensive than the price received for exports. These factors lead to the fact that the cost of introducing tourism in less developed countries tends to get higher than the benefits, especially with regard to the local, disadvantaged communities (Tourism Concern, 2000).

\section{Economic Impacts}

Tourism has a variety of economic impacts. Tourists contribute to sales, profits, jobs, tax revenues, and income in an area. The most direct effects occur within the primary tourism sectors --lodging, restaurants, transportation, amusements, and retail trade. Through secondary effects, tourism affects most sectors of the economy. An economic impact analysis of tourism activity normally focuses on changes in sales, income, and employment in a region resulting from tourism activity (Stynes, 1997).

The impacts of tourism can be said to be more than the outcome of a certain tourist event or facility. Impacts appear as modified human behavior, originating from the "interactions between the agents of change and the sub-systems on which they impinge". The links between the different categories of tourism impacts; economic, physical and social are very close and thus interpreted and indicated complex and difficult to measure and plan. The tolerate limits of a destination area's carrying capacity, concerning the economic, physical and social sub-systems determine the dimension and direction of the tourist impact. These limits have been exceeded when the impacts become negative. When compared with physical and social impacts of tourism, the economic ones are relatively easily measurable. This is because the physical and social impacts are often composed by intangibles and incomparable, thus hard to quantify or analyze numerically (Mathieson and Wall, 1992). One of the key issues arising when discussing economic impacts of tourism is scale (Mason, 2003). And as Douglas Pearce (1989) notes: the size, diversity and vitality of an economy together with the degree of tourism, local participation and external influences will further influence the impacts of tourism on a destination (Krause).

Although all the factors above are interwoven in real life and the economic impacts affect and are affected by the natural environment and the socio-cultural factors, the impacts studied here, shall be those of economic impacts.

It should be kept in mind that tourism impacts are not only social, environmental or economic, but there are many inter-related levels. The economic impacts are particularly obvious in less developed countries. However, there seems to be a trade-off situation, where the positive impacts outweigh the negative ones (Mason, 2003). In general, the study of economic impacts has tended to have a more positive point of view, focusing on the number of benefits that tourism can bring although these benefits have been accompanied by a number costs (Mathieson and Wall, 1992).

There are several other categories of economic impacts that are not typically covered in economic impact assessments, at least not directly. For example:

- Changes in prices -- tourism can sometimes inflate the cost of housing and retail prices in the area, frequently on a seasonal basis.

- Changes in the quality and quantity of goods and services - tourism may lead to a wider array of goods and 
services available in an area (of either higher or lower quality than without tourism).

- Changes in property and other taxes - taxes to cover the cost of local services may be higher or lower in the presence of tourism activity. In some cases, taxes collected directly or indirectly from tourists may yield reduced local taxes for schools, roads, etc. In other cases, locals may be taxed more heavily to cover the added infrastructure and service costs. The impacts of tourism on local government costs and revenues are addressed more fully in a fiscal impact analysis.

- Economic dimensions of "social" and "environmental" impacts - There are also economic consequences of most social and environmental impacts that are not usually addressed in an economic impact analysis. These can be positive or negative. For example, traffic congestion will increase costs of moving around for both households and businesses. Improved amenities that attract tourists may also encourage retirees or other kinds of businesses to locate in the area.

\section{Direct, Indirect and Induced Effects}

A standard economic impact analysis traces flows of money from tourism spending, first to businesses and

Government agencies where tourists spend their money and then to :

- Other businesses -- supplying goods and services to tourist businesses,

- Households - earning income by working in tourism or supporting industries, and

- Government -- through various taxes and charges on tourists, businesses and households

Formally, regional economists distinguish direct, indirect, and induced economic effects. Indirect and induced effects are sometimes collectively called secondary effects. The total economic impact of tourism is the sum of direct, indirect, and induced effects within a region. Any of these impacts may be measured as gross output or sales, income, employment, or value added. See the glossary for definitions of these terms.

Direct effects are production changes associated with the immediate effects of changes in tourism expenditures. For example, an increase in the number of tourists staying overnight in hotels would directly yield increased sales in the hotel sector. The additional hotel sales and associated changes in hotel payments for wages and salaries, taxes, and supplies and services are direct effects of the tourist spending.

Indirect effects are the production changes resulting from various rounds of re-spending of the hotel industry's receipts in other backward-linked industries (i.e., industries supplying products and services to hotels). Changes in sales, jobs, and income in the linen supply industry, for example, represent indirect effects of changes in hotel sales. Businesses supplying products and services to the linen supply industry represent another round of indirect effects, eventually linking hotels to varying degrees to many other economic sectors in the region.

Induced effects are the changes in economic activity resulting from household spending of income earned directly or indirectly as a result of tourism spending. For example, hotel and linen supply employees, supported directly or indirectly by tourism, spend their income in the local region for housing, food, transportation, and the usual array of household product and service needs. The sales, income, and jobs that result from household spending of added wage, salary, or proprietor's income are induced effects.

By means of indirect and induced effects, changes in tourist spending can impact virtually every sector of the economy in one way or another. The magnitude of secondary effects depends on the propensity of businesses and households in the region to purchase goods and services from local suppliers. Induced effects are particularly noticed when a large employer in a region closes a plant. Not only are supporting industries (indirect effects) hurt, but the entire local economy suffers due to the reduction in household income within the region. Retail stores close and leakages of money from the region increase as consumers go outside the region for more and more goods and services. Similar effects in the opposite direction are observed when there is a significant increase in jobs and household income (Stynes, 1997).

\section{Measuring the Economic Impact}

The economic impact of tourist expenditure can be calculated by using the multiplier analysis whereas estimating the economic impact of tourism development projects, project appraisal techniques such as cost-benefit analysis are more appropriate (Cooper, Fletcher, Gilbert, Wanhill and Shepherd, 1998). However, as the black or grey turnover is relatively high in many less developed countries, the actual economic impacts of tourism are quite hard to measure. In a black economy a considerable amount of the income from tourism does not flow through the official channels (Rátz and Puczkó, 2002).

Christopher Holloway offers four ways of measuring the economic impacts of tourism, that is, the effect on income, employment, the area's balance of payments and finally the effect on investment and development (Holloway, 1998). Figure 1 shows the economic impacts of tourism.

\section{Other Concerns in Economical Consequences of Tourism Industry}

\subsection{Balance of Payments}

"The balance of payments account is a record of economic transactions during a period of time (usually a year) 
between residents of the country in question and the rest of the world".

The income a country gains from tourism can help to balance the national balance of payments. This is considered important as the country then gains foreign, or hard, currency. Effects on the balance of payments are considered the most known economic impacts of tourism. The balance of payments account includes the value of all goods, gifts, loans, foreign aid and gold that comes in or leaves the country as well as the connections between these.

Tourism affects the balance of payments in two ways; effects within the country and effects on international tourism. This is useful to know in order to calculate foreign earnings in the balance of payments and compare them with the costs. In other words it is useful in the sense of knowing if more money is leaving the country than what is earned from international tourism (Mathieson and Wall, 1992). The amounts spent on international transport are however not included as part of the income generated from tourism in the balance of payments. This is mainly due to the fact that the transport companies usually are registered in the country of departure, whereby the destination may not account for the amount spent on transport as income. (Rátz and Puczkó 2002, 66.)

The effects of tourism on the balance of payments can also be divided into three categories; primary, secondary and tertiary effects. The primary effects are direct and comparatively easily measurable. They concern the actual consumption by foreign tourists as well as the consumption of the country's citizens abroad and occur only when international boundaries are crossed. The secondary and tertiary effects are more complicated and hard to measure. The secondary effects are divided into direct secondary effects, indirect secondary effects and induced secondary effects. Direct secondary effects involve, among others, imports, commissions to travel agents and outflows in terms of e.g. dividend payments to foreign investors (Airey, 1978). The indirect secondary effects include secondary transfers of initial tourist expenditure. Induced secondary effects involve the proportion of payments remitted abroad in terms of expatriate labor. The tertiary effects are the flows of currency that are not set up by direct tourist expenditure (Ibid). They involve for example products that have been imported for travelling abroad; such as suitcases as well as the investment opportunities that tourism creates (Rátz and Puczkó 2002, 63).

The expenditure by overseas visitors in the country together with the expenditure by residents abroad is considered to be the travel account or travel balance and the results are compared in order to determine which number is larger. The tourism balance on the other hand, takes into account "all readily identifiable items of international visitor expenditure". The travel account might be of use when preliminary assessing the involvement of a country in international tourism (Mathieson and Wall, 1992).

\subsection{Currency Flows}

International price and currency controls such as currency restrictions - in terms of the volume that can be taken abroad, import duties and export taxes can manipulate the volume of tourist traffic. The direction and dimension of currency flows are determined by factors that make the difference between gross and net foreign earnings. When supply and demand is stable, they include the tendency to import, expatriate labor and the nature of capital investment. The propensity to import takes every unit of tourist expenditure that is moved to another area to purchase goods or services into account and thus shows the likelihood of leakage.

The imports can be either direct or indirect and are usually influenced by the importing country's size and development status as well as by its import policies. When the 'home country' is unable to supply the labor domestically, it needs to employ expatriate, foreign, labor. The amount of leakage from the exporting country is larger when the total expatriate earnings are high (Mathieson and Wall, 1992). It is generally thought that most of the tourism-related labor is semi-skilled or unskilled, thus it would seem as if the less developed countries would possess their tourism labor domestically and thereby not be in need of expatriates. This again would save them from the outflow of currency in terms of remittance payments. Particularly in less developed countries foreign capital investment has been a very common feature in the tourism industry. It is a result of two major conditions; the encouragement of foreign investment in early tourism development and the rise of the multinational corporations and it has lead to high leakage (Ibid).

\subsection{Income Generation and the Distribution of Tourist Spending}

Tourism is very flexible concerning price and income and decisions are heavily influenced by minor changes in price and income. As price elasticity has frequent and immediate effects it is more easily recognizable than the elasticity of income. These changes are more progressive and the effects can only be identified after a certain period of time.

The total income earned from tourist spending, increases when the area of measurement is extended. This is due to the fact that leakage is reduced and thus reflects the ability of a larger area to supply the goods and services needed, instead of importing (Mathieson and Wall, 1992). Some of the tourism industry establishments are totally dependent on tourist spending, whereas others also profit from the local residents and thus gain only a small part of their revenues from tourism. Governments get income from tourism through direct taxation on tourist manpower, tourism and transport enterprises, fees and service charges, as well as from indirect taxation 
on customs duties, goods consumed by tourists, interest and loan repayments as well as from revenue gained by government-owned or financed tourism enterprises (Ibid).

\subsection{Employment}

Tourism employs more and more people in the less developed countries. However, they are mostly employed at the lower performance level, in order to keep the salaries low. The managerial staff is on the other hand brought with the multinational corporations. Thus the income from tourism is not sufficiently let to grow in the destinations (Hemmi, 1999). However, it is generally agreed that tourism does create employment and that this is a beneficial impact (Mathieson and Wall, 1992).

There are three different types of employment offered by tourism. Direct employment is employment at tourism facilities, resulting from tourist consumption. Indirect employment is also a result of employment in the tourism supply sector, however not directly resulting from tourist expenditure. Induced employment occurs as additional employment resulting from tourism multiplier effects (Ibid). To a certain extent, the impacts of employment and income are related as direct, indirect and induced effects can be distinguished in both cases. There is also a connection between increased income and increased employment, although the pace of growth is not necessarily of equal standard. The type of tourist activity influences the effects on employment, as different types of tourism are labor-intensive at different levels; for example the accommodation facilities employ a large number of labor force at destinations and thus often require greater amounts of capital as well.

Effects of employment are also influenced by the local skills and the employment structure as well as the seasonality of employment often thought of as disadvantages (Mathieson and Wall, 1992).

The employment effects of tourism are often invisible or covered as tourism might employ people from other sectors or people that would not otherwise be considered to belong to the available workforce, thus it is difficult to measure and see the real impacts tourism has on employment. The seasonal employment may also attract people away from full-time employment whereby non-tourist industries might be discouraged from stationing in the area. Generally, it can be said that the fact that tourism creates employment is beneficial to the economy (Ibid).

\subsection{Entrepreneurial Activity}

Co-operation and linkages between the local entrepreneurs of tourism and the tourist sector depends on the demand of different types of supply and produce and what kind of capacity the local suppliers have to meet these demands. It also depends upon how the tourism industry has developed in the area and the kind of development that has taken place. It is important that the tourism industry is serviced by local producers in order for the local economy to benefit. In order for this to happen, the linkages between the local entrepreneurs should be strengthened. Just as employment, local entrepreneurial activity is seen as being beneficial for the economy, it is regarded as a positive impact of tourism activity, one indirect benefit being the improved economic and social services. However, the direct profits tend to benefit only a minor part of the local community (Mathieson and Wall, 1992).

\subsection{Opportunity Costs}

It is commonly known that tourism involves opportunity costs, although they are not easily definable. When destination areas invest in the development of tourism, they rarely consider what the same resources could provide when invested in another industry. Thus what needs to be researched is "the relative economic benefits of investing in tourism as opposed to investing in another industry"; these are the opportunity costs.

In order to measure the opportunity costs, the possibilities that have been relinquished when choosing tourism should be carefully examined, outlined and valued. Because of the difficulty in measuring and seeing these costs, they are often forgotten, thus leaving the economic impacts of tourism look more beneficial than they perhaps are (Mathieson and Wall, 1992).

\subsection{Overdependence}

When destinations become over dependent on tourism, they make themselves vulnerable to tourists' changes in demand. Tourism is a sensitive industry and influenced by change, both domestic and international. The change can comprehend changes in price and trends, political events and political unrest as well as accessibility of electricity. Areas with political unrest have lost out on tourists, who choose to travel to other, more stable destinations. In order to avoid economic disturbance due to changes in demand, tourist destinations should promote a diversified tourist industry and base economy (Mathieson and Wall, 1992).

\subsection{Inflation and Land Value}

The changes in land-use patterns from an agricultural society to the tourism industry introduces modified land-use patterns as tourism increases land prices as a result of competition and thus encourages sales. This means that small units of land are sold at high prices thus contributing to inflation. This affects young residents when they try to buy land. Simultaneously self-sufficiency is decreased and dependency on national and international economic conditions is increased. 
The consequences of inflation might arise in many different ways. Rich tourists buy products at higher prices and when the suppliers realise that this increases their profits, they raise the prices further. This means that companies servicing tourists easily can compete with those servicing the local population (Mathieson and Wall 1992). As a consequence however, the locals are forced to pay more and maybe even have to go further away in order to get what they need, as the local enterprises concentrate on a more limited range of products (Ibid).

\subsection{Seasonality}

As the tourism product cannot be stored and is highly seasonal, it needs to earn enough during high season in order to fight and survive the decline during the rest of the year.

This also has obvious implications for employment and investment. The seasonality of tourism leads to a division between high- and low season. Take the hotel sector as an example. Some of the hotels are closed during low season, whereas others suffer great losses in income (Mathieson and Wall, 1992). As fixed costs cover a big part of the total costs, the hotels try to ensure as good as possible incomes. The accommodation sector is however not the only sector suffering from seasonality. Tour operators face reluctance from outside investors to get financially involved in marketing seasonal enterprises. This has lead to the fact that local investors are carrying a much bigger financial responsibility (Ibid).

\subsection{Leakage}

Rátz and Puczkó $(2002,82)$ define leakage as "financial processes through which less money gets back into the economy". Leakage occurs mainly in two different ways; as import or export leakage. When tourists demand standards that the host country cannot supply, import leakage occurs and this especially in less developed countries. As import is necessary, most of the income from tourist expenditure leaks out of the country in order to pay for the imports. According to UNCTAD (UNEP 2004) import-related leakage for less developed countries and small economies is on average between $40 \%$ and $50 \%$ of gross earnings whereas the same figure for advanced and diversified economies is between $10 \%$ and $20 \%$. Export leakage occurs when foreign investors, financing resorts and hotels, collect their profits back to their country of origin. This is a substantial part of the leakage that occurs in less developed countries as multinational corporations are the only ones there with enough capital to invest in tourism infrastructure and facility construction. (UNEP 2004). The main argument for tourism development in less developed countries has been that of foreign exchange. However, it seems as if those countries that need the foreign exchange make the lowest profits. (Krippendorf, 1987). As they are the least developed ones, they are also the ones that need to import the most. The most extreme cases show that 80 to 90 percent of the foreign exchange leaks out before any improvements have taken place (Ibid).

\section{Capital Investment and Development}

Another factor why the money does not reach the local economy, is that the governments of the host destinations usually offer tax-free spurs to foreign developers and investors and thus the income they gain from their all-inclusive resorts, leak out of the country and the local economy gains very little. As an example, it has been estimated that $60 \%$ of the $£ 4$ billion annual tourism revenue in Thailand leaves the country. As the all-inclusive are westernized from beginning to end, the tourists end up spending their money in western hotels, they consume western food and drink and thus the small amount of money that actually reaches the destinations, mostly leaves it again as profits to western companies in terms of imports. (Tearfund, 2002).

\section{External Costs}

The development of tourism also impose other costs on the residents of tourism destinations, such as increased costs of garbage handling and increased costs of maintaining tourist attractions that have been damaged by excess of the carrying capacity and vandalism. However, there has been little study into these kinds of costs. (Mathieson and Wall, 1992).

In brief, the tourist system changes overtime which means that as tourist numbers increase, the control by locals decreases thus increasing the control by the tourism industry which again leads to increased impacts (Prosser, 1994).

\section{Leveraging Destination Marketing for Economic Benefits}

Paralleling the sophistication in the tourism industry's product is a new sophistication in marketing. Destinations are also spending ever greater amounts on tourism marketing to create greater awareness of the destination in target markets and facilitate industry's efforts to "close the sale." Traditional destination marketing has focused on creating awareness of the destination in target markets, usually with some form of destination branding or logo "call to action." Recognition of the importance of tourism has carried with it ever increasing investments by many jurisdictions seeking to strengthen their tourism sector and compete effectively in the marketplace.

There is also a recent emphasis on linking tourism with a destination's exports. This relates to the "branding" approach many destinations take in positioning their tourism product against those available worldwide.

\section{Growth Areas within the Tourism Sector}

Several segments of the tourism industry have experienced substantial growth, building on lower travel costs and 
more disposable income available for tourist activities. Examples range from major attraction areas such as the Disney, Branson and Universal facilities to ski and golf resorts. In the Caribbean, the introduction of Atlantis in the Bahamas as a major themed resort is one such example of the creation of a "destination" product that is sufficiently large to generate its own market above and beyond the destination. Here again, destination attractions rely on significant marketing power and prowess to generate year round business on a consistent basis. Another product area that has emerged over the last two to three decades as one of the leading products is the cruise experience. Similar to the all-inclusive resort experience, cruise travel offers a single, all-inclusive price, modern facilities, an opportunity to see interesting destinations, and safety and security. Consistently voted by consumers as one of the top products in the world, the growth in the cruise industry has reflected this market interest.

Future product trends have been forecast by the World Tourism Organization (WTO) in their

Tourism: 2020 Vision publication (1998). The WTO predicted that the following five tourism products will emerge as the hottest trends over the next two decades (WTO 1998):

1) Adventure travel - with most of the world already being explored, the trend will be for tourists to travel to the world's highest peaks, to underwater sites (such as the Titanic) and places at the "ends of the earth" (such as Antarctica).

2) Cruises - the cruise sector is expected to expand at the high annual growth rates that have been seen in recent years.

3) Cultural tourism - Europe, the Middle East and Asia are predicted to enjoy especially strong tourism growth.

4) Ecotourism - trips containing a nature component will continue to gain in popularity.

5) Themes - thematic tourism, where a special interest is the main travel motivator, is also expected to see strong growth.

One of the interesting features about WTO's "hottest trends" forecasts relates to the implications for potential economic impacts. Four of the five trends (excluding cruise) point to increasing expenditures by visitors on activities and experiences. This, in turn, results in more business for smaller tourism enterprises in any given destination. The result is a more active small business community serving the tourism industry and tourism markets, greater opportunities for new business development and greater potential for local involvement in tourism beyond just employment.

\section{Measuring Tourism's Contribution}

As the preceding discussion indicates, the contribution of tourism extends well beyond the quantitative measure typically quoted - economic impacts and contribution to gross domestic products. With an integrated tourism management plan in place, destinations are seeking to leverage tourism destination branding to enhance exports of other products, strengthening impacts on quality of life of the destination's residents, and enhancing small business development.

\section{Tourism as Trade}

Tourism is an "invisible export industry" which means that there is no tangible product to deliver. In tourism, just as in banking, the consumer collects the service personally from the point of production. Thereby, there are no direct freight costs outside the exporting destination's boundaries unless it owns the transportation used. This is extremely unusual in less developed countries and thus tourism is sold "free on board" (f.o.b.). In advanced countries on the other hand, the exporting country often owns e.g. the airline and thus tourism is sold both f.o.b. and c.i.f., which includes cost, insurance and freight. Tourists need auxiliary goods and services while staying at a destination. These include transportation facilities, water supply, sewerage systems and retailing and they need to be created, further developed or imported, depending on accessibility. Tourism is a fragmented product and it is a very precarious export being sensible to external forces, highly elastic pricing and income as well as dependent on seasonal changes. (Mathieson and Wall, 1992).

\section{Tourism and Economic Development}

The benefits and costs of tourism development are different in different areas. Some of these are characteristic of the changes in the destination area's economic structures and geographical locations, the most obvious difference being that between less developed and advanced areas. In less developed countries the level of income is usually low, the distribution of income and wealth is usually uneven, there are high levels of unemployment and underemployment, the industrial developments are barely existing, there is a strong dependence on agriculture and the service and manufacturing industries are usually under foreign ownership. These factors can also be associated with disparities in wealth between less developed countries, a considerable leakage of profits, high inflation and a lack of foreign exchange. Many of the factors mentioned above do trouble advanced countries as well. However, the reasons are usually other kinds of economic factors. It is also clear that increased tourist expenditure and foreign investment has quite different effects in terms of scale if injected to a less developed as opposed to an advanced economy. However, not only the economic development of the destination, but also the 
source of tourists and investment influence the directions of monetary flows, distribution of benefits and employment and income characteristics.

Tourism is relatively new in less developed countries, but it has expanded rapidly over a short period of time, thus heavily burdening the local infrastructure and human resources, not always in a positive sense. However, there is a desire to transform from a traditional agricultural economy into an industrial economy in order to develop economically. This would however require vast amounts of capital and foreign earnings or loans, which the less developed countries are unlikely to possess; thus their governments have turned to tourism, as a fast way of acquiring the revenue needed for industrialization. Supporters of tourism development in less developed countries also indicate that tourism despite these positive impacts also would lighten problems of urban unemployment and provide a substitute for traditional exports facing less secure futures. These kinds of arguments have lead to the fact that, especially among policy-makers in less developed countries, tourism is seen as a viable strategy for economic growth (Mathieson and Wall, 1992).

Developing tourism in less developed poor countries is also appealing since the profits usually are higher for the industrialists here, as prices tend to be a lot cheaper due to the low standard of living (Krippendorf, 1987). On the other hand, when compared with export of primary products, tourism does have a comparative advantage in that the host destination has more control over pricing and thus the developing country is not subject to the whims of commodity exports. Compared with raw materials, tourism is also more income-elastic, as small increases in income of the potential tourists might lead to considerable growth in tourist arrivals and tourist receipts thus favoring the less developed countries (Mathieson and Wall, 1992).

\section{Conclusion}

Tourism has historically been regarded in most economies as a second cousin to other economic sectors ranging from resource industries to manufacturing. Indeed, in the past several decades of economic reporting, tourism expenditures were always hidden in various service categories (Antigua and Barbuda Tourism Development Programme, 2003).

Tourism is an activity that involves a large array of retail and service businesses. The sectors most affected by tourism are hotels and other lodging facilities, eating and drinking establishments, and amusement and recreation facilities such as theme parks and ski resorts. One of the largest expenses in these industries is salaries and wages for employees. Often these employees are from the local area. However, for some businesses that are highly seasonal, employees may come from outside.

Some communities worry about relying too heavily on tourism. Some of the negative aspects of tourism may include the highly seasonal nature of employment, the low average wage level in tourism related industries, the congestion and increases in prices of products and real estate that tourists can cause. However, well managed tourism can complement other economic activities in a community (Leones, 1995).

Considering the direct, indirect positive and negative economic impacts of tourism industry, it could be concluded that with short-term and long-term strategic planning and using the specific abilities and tourism products of developing countries, which suffer from some indices as unemployment, limits in earning and currency flows, inflation and other problems, most of their economic problems can be solved.

\section{References}

Antigua and Barbuda Tourism Development Programme. (2003). Tourism's Economic Impacts Increasing the Contribution to Prosperity, Prepared by: KPMG Consulting LP, February, 2003: [Online] Available: http://www.tourismantiguabarbuda.gov.ag/tourism_programs/pdf/planning_eis_study.pdf.

Airey, D. (1978). Tourism and the balance of payments. Tourism International Research - Europe. $3^{\text {rd }}$ quarter. 2-16. In Mathieson, A. and Wall, G. 1992. Tourism. Economic, Physical and Social Impacts. Essex: Addison Wesley Longman Limited.

Blake, A., and Gillham, J. (2001). A Multi-Regional CGE Model of Tourism in Spain. Paper prepared for the European Trade Study Group annual conference, Brussels, September 2001.

Blake Adam. (2008a). Tourism and Income Distribution in East Africa. International Journal of Tourism Research, 10(6), pp. 511-524.

Cooper, C. Fletcher, J. Gilbert, D. Wanhill, S., and Shepherd, R. (1998). Tourism Principles and Practice. Second edition. Essex: Pearson Education Limited.

Hemmi, J. (1999). Matkailun globalisaatio ja talous in Saukkonen, P. (1999). Matkailu ja globalisaatio. Helsinki: Suomen YK-Liitto.

Holloway, C. (1998). The Business of Tourism. Essex: Pearson Education Limited.

Kalisch, A. (1996). Tourism and Fair Trade in Trading Places: Tourism as Trade. London: Tourism Concern.

Krause, L. The Economic Impacts of Fair Trade in Tourism: [Online] Available: http://reilumatkailu.meizo.com/sites/reilumatkailu/files/THE_ECONOMIC_IMPACTS.pdf 
Krippendorf, J. (1987). The Holiday Makers. Understanding the Impacts of Leisure and Travel. Oxford: Butterworth-Heinemann.

Laffargue J. P. (2009). The economic and social effects of tourism activities and tourism policies. A survey of the computable general equilibrium (CGE) models approach, CEPREMAP, Version septembre 2009, Docweb no 0905 .

Leones, J. (1995). Tourism Trends and Rural Economic Impacts. Consumer Profiles \& Tourism Trends. [Online] Available: http://ag.arizona.edu/arec/pubs/dmkt/TourismTrends.pdf

Mann, M. (2000). The Community Tourism Guide. London: Earthscan Publications Ltd.

Mason, J. (2002). Qualitative Researching, 2nd edition. London: SAGE Pubilcations Ltd.

Mowforth, M., and Munt, I. (1998). Tourism and Sustainability. New Tourism in the Third World. London: Routledge.

Mathieson, A., and Wall, G. (1992). Tourism. Economic, Physical and Social Impacts. Essex: Addison Wesley Longman Limited.

Prosser, R. (1994). Societal Change and the Growth in Alternative Tourism (pp.19-39) in Cater, E. and Lowman, G. (eds.) Ecotourism. A sustainable Option? West Sussex: John Wiley \& Sons Ltd.

Rátz, T., and Puczkó, L. (2002). The Impacts of Tourism. An Introduction. Hämeenlinna: Häme Polytechnic.

Stynes, D. J. (1997). Economic Impacts of Tourism, A Handbook for Tourism Professionals, Illinois Bureau of Tourism, Illinois Department of Commerce and Community Affairs, Prepared by the Tourism Research Laboratory at the University of Illinois at Urbana-Champaign, Fall, 1997: [Online] Available: http://150.214.182.12:8080/turismo/turismonet1/economia\%20del\%20turismo/economia\%20del\%20turismo/eco nomic\%20impacts\%20of\%20tourism.pdf

Tearfund. (2002). Worlds Apart - A call to responsible global tourism? [Online] Available: http://www.tearfund.org/uploads/documents/Worlds\%20Apart\%20tourism\%20report.pdf. (10.01.2004).

Tourism Concern. (2000a). Bulletin 2 Corporate Social Responsibility. [Online] Available: http://www.tourismconcern.org.uk/pdfs/corporate.pdf. (20. 01. 2004).

Tourism Concern. (1999). The International Network on Fair Trade in Tourism. [Online] Available: http://www.tourismconcern.org.uk/pdfs/introduction.pdf. (20. 01. 2004).

UNEP. (2004). United Nations Environment Programme. Economic Impacts of Tourism. [Online] Available: http://www.uneptie.org/pc/tourism/sust-tourism/economic.htm. (21. 04. 2004).

Wattanakuljarus A. (2006). The Nationwide Economic and Environmental Impacts of Tourism a Computable General Equilibrium Approach for Thailand: [Online] Available: http://www.idrc.ca/uploads/user-S/11738541401Anan_FReport.pdf

Wattanakuljarus A., and I. Coxhead. (2008). Is Tourism-Based Development Good for the Poor? A General equilibrium Analysis for Thailand", Journal of Policy Modeling, 30, pp.929- 955. [Online] Available: https://www.msu.edu/course/prr/840/econimpact/pdf/ecimpvol1.pdf

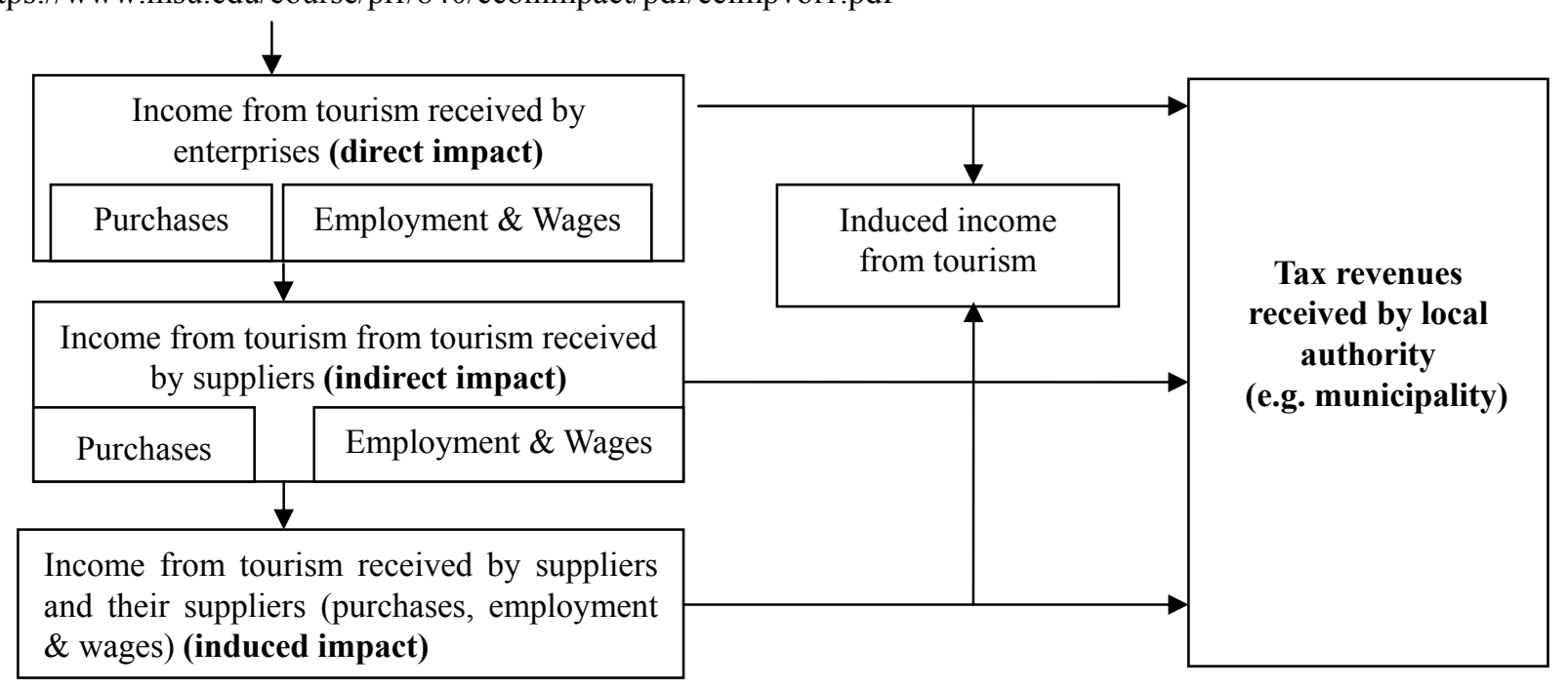

Figure 1. Model of the economic impacts of tourism (Rátz and Puczkó, 2002) 